\title{
Bone copper content in sheep in relation to their drinking water source
}

\section{Contenido de cobre óseo en ovinos en función de su fuente de agua de bebida}

\author{
Arturo F. Castellanos-Ruelas ${ }^{1 *}$, J. Gabriel Rosado-Rubio ${ }^{1}$, David A. Betancur-Ancona ${ }^{1}$, Manuel Heredia y \\ Aguilar ${ }^{2}$ \\ ${ }^{1}$ Facultad de Ingeniería Química. Universidad Autónoma de Yucatán. Campus de Ciencias Exactas e Ingenierías. Periférico \\ Nte. km 33.5. Tablaje Catastral 13615. Col. Chuburná de Hidalgo Inn. C.P. 97203. Mérida, Yuc. México. \\ ${ }^{2}$ Independent advisor in ovine production. \\ *Corresponding author: cruelas@correo.uady.mx
}

Scientific note received: June 21, 2016 accepted: March 03, 2017

\begin{abstract}
The aim was to estimate the $\mathrm{Cu}$ content in the bones of grazing sheep and relate it to their drinking water. Cu was analyzed by taking bone biopsies. Samples from the twelfth rib were taken in 107 animals and water samples were collected from forty wells in the same farms located in four agroecological areas in Yucatán state, Mexico. $\mathrm{Cu}$ was analyzed by atomic absorption. Data were analyzed using the least squares method. $\mathrm{Cu}$ content in bone tissue was: weaned $0.66^{a}$; Females prior to first gestation $0.57^{b}$ and ewes $0.64^{a} \mathrm{mg} / \mathrm{kg}^{-1}$. Normal content in bone is $2-3$ $\mathrm{mg} / \mathrm{kg}^{-1}$, indicating a deficiency in the animals. $\mathrm{Cu}$ in water was $0.15^{a b}, 0.12^{b}, 0.16^{a b}$ and $0.19^{a} \mathrm{mg} / \mathrm{L}^{-1}$ in the center, east, west and south part of the State respectively. $\mathrm{Cu}$ concentration in water for animal consumption was low. In conclusion, $\mathrm{Cu}$ deficiency was diagnosed in grazing sheep that could be associated with the low $\mathrm{Cu}$ content in the drinking water.
\end{abstract}

Keywords: Copper, bone biopsy, grazing, sheep

RESUMEN. El objetivo fue estimar el contenido de $\mathrm{Cu}$ en hueso de ovejas en pastoreo y relacionarlo con el agua consumida. Se tomaron biopsias de décima segunda costilla en 107 animales y muestras de agua de cuarenta pozos, en el estado de Yucatán, México en cuatro zonas agroecológicas. El Cu se analizó por absorción atómica. Los datos se analizaron mediante mínimos cuadrados. El contenido de $\mathrm{Cu}$ en hueso fue: destetados $0.66^{a}$, en novillonas $0.57^{b}$ y ovejas adultas $0.64^{a} \mathrm{mg} \mathrm{kg}^{-1}$. El contenido normal está entre 2 y $3 \mathrm{mg} \mathrm{kg}^{-1}$, siendo estos resultados inferiores, implicando deficiencia en los animales. El contenido en el agua fue $0.15^{a b}, 0.12^{b}, 0.16^{a b}$ y $0.19^{a} \mathrm{mg} \mathrm{L}^{-1}$ en el Centro, Este, Oeste y Sur del estado, respectivamente. Estos resultados fueron bajos. En conclusión se diagnosticó deficiencia de $\mathrm{Cu}$ en ovinos en pastoreo que podrían estar asociada al bajo contenido de $\mathrm{Cu}$ en el agua consumida.

Palabras clave: Cobre, biopsia de hueso, pastoreo, ovejas

\section{INTRODUCTION}

Mineral deficiencies are among the most important nutritional problems in grazing ruminants in tropical areas across the world. This is a consequence of mineral imbalances in pastures, causing a deficient animal performance. Pioneer studies (McDowell and Arthington, 2005) underlined that phosphorus deficiency was the most important and imbalances among microminerals were also to be considered. Mineral content of forages is provided by soil type and water resources. In the Yucatán peninsula soils are sedimentary and calcareous, and underground water is alkaline with high calcium content (COTECOCA 1978). Therefore, an excess of calcium, combined a low phosphorous content associated with either a lack or excess of microminerals induces a mineral imbalance in the soil-plant-animal relationship (Whitehead 2000).

In the state of Yucatán sampling and analyses of forages have been performed and confirm the situation mentioned above. Excess of calcium and iron, and deficiencies of phosphorus, copper, zinc, selenium and cobalt were detected (Millán et al. 
1990, Vivas et al. 2011). Copper and zinc deficiencies in pastures were also reported in the neighboring state of Quintana Roo (Cabrera et al. 2009), as well as in Chiapas state (Muñoz et al. 2014), in the south of the state of Mexico (Vázquez et al. 2011) and recently in Tlaxcala state (Muñoz et al. 2015), among other places. Various trials of mineral supplementation with grazing ruminants have been carried out in Yucatán (Segura and Castellanos 1999, Cetz et al. 2005) and a positive productive response of supplemented animals is widely reported (Muñoz et al. 2015).

Among the microminerals, copper $(\mathrm{Cu})$ is one of the most important since it's a constituent of enzymes that participate in the immune and antioxidant systems, among other functions (Suttle 2010). But special attention must be considered since $\mathrm{Cu}$ is also a heavy metal that may be bioaccumulated in the body of both animals and humans causing toxicity and death (NRC, 2005). Despite the key role of water in livestock production, studies on water quality and its relationship to animal mineral status in Mexico are scarce. Recently, SaucedoTerán et al. (2017) analyzed the water quality of various cattle drinking sources in northern Mexico and found differences depending on their origin. In Yucatan, no research was found in the specialized literature on water quality in farms producing ruminants on pasture. The objective of the present study was to estimate the Cu status in grazing sheep in different physiological conditions and relate it to $\mathrm{Cu}$ concentration in the drinking water depending on the geographical location of the farms, and the type of soil.

\section{MATERIALS AND METHODS}

Sampling was carried out during the rainy season (July to October) in the state of Yucatán. The state area was divided into four geographical zones according to traditional soil use: Center (C) sisal production, East (E) livestock, South (S) crops and West (W) undetermined (Figure 1).

\section{Bone biopsy samples}

The census of the Sheep Farmers Association of Yucatan was used to identify farms susceptible to be sampled in all four geographical areas of the state (Figure 2). Bone biopsy samples were taken from grazing ovine. A total of 107 samples were taken as follows: 34 were taken from recently weaned lambs; 37 from females prior to first gestation (yearlings) and 36 from adult ewes. Biopsy was taken from the twelfth rib on the right side of the body using the technique described by Little (1972). Bone samples were placed in plastic containers in a solution of formaldehyde at $10 \%$ for preservation, until analysis.

\section{Copper analysis of bone biopsy}

Approximately $0.5 \mathrm{~g}$ of bone was placed in a porcelain capsule; $1 \mathrm{~mL}$ of $\mathrm{HCl}$ solution was added and deposited in a water bath. After approximately $10 \mathrm{~min}, 3$ to 5 additional drops of $\mathrm{HCl}$ were applied. The addition of acid was repeated twice as long as the sample solution remained in the water bath. Then the capsules were placed in an oven at 500 ${ }^{\circ} \mathrm{C}$ for $6 \mathrm{~h}$ or until gray ashes were obtained. They were left to cool, $0.5 \mathrm{~mL}$ of $\mathrm{HCl}$ (1:4) was added and the mixture was transferred to a beaker of 100 $\mathrm{mL}$ where $5 \mathrm{~mL}$ of $\mathrm{HCl}$ were added and evaporated to dryness in a water bath in order to remove $\mathrm{SiO}_{2}$. The residue was moistened with $2 \mathrm{~mL}$ of $\mathrm{HCl}$; $50 \mathrm{~mL}$ of water were added and heated for a few minutes in a water bath. The sample was transferred to a volumetric flask of $100 \mathrm{~mL}$, cooled abruptly, gauged to the mark, continuously shaken, and then filtered (Fick et al. 1979). Cu content was determined using a Perkin Elmer model 500 atomic absorption spectrophotometer, equipped with the respective hollow cathode lamp, using the methodology described by Fick et al. (1979).

\section{Well water samples}

Water samples were taken from the wells located in the same farms where bone samples were obtained. Since there were more farms in the $E$ area, more water samples were taken from this region. Twelve samples were taken in farms in $\mathrm{C}$ area, 


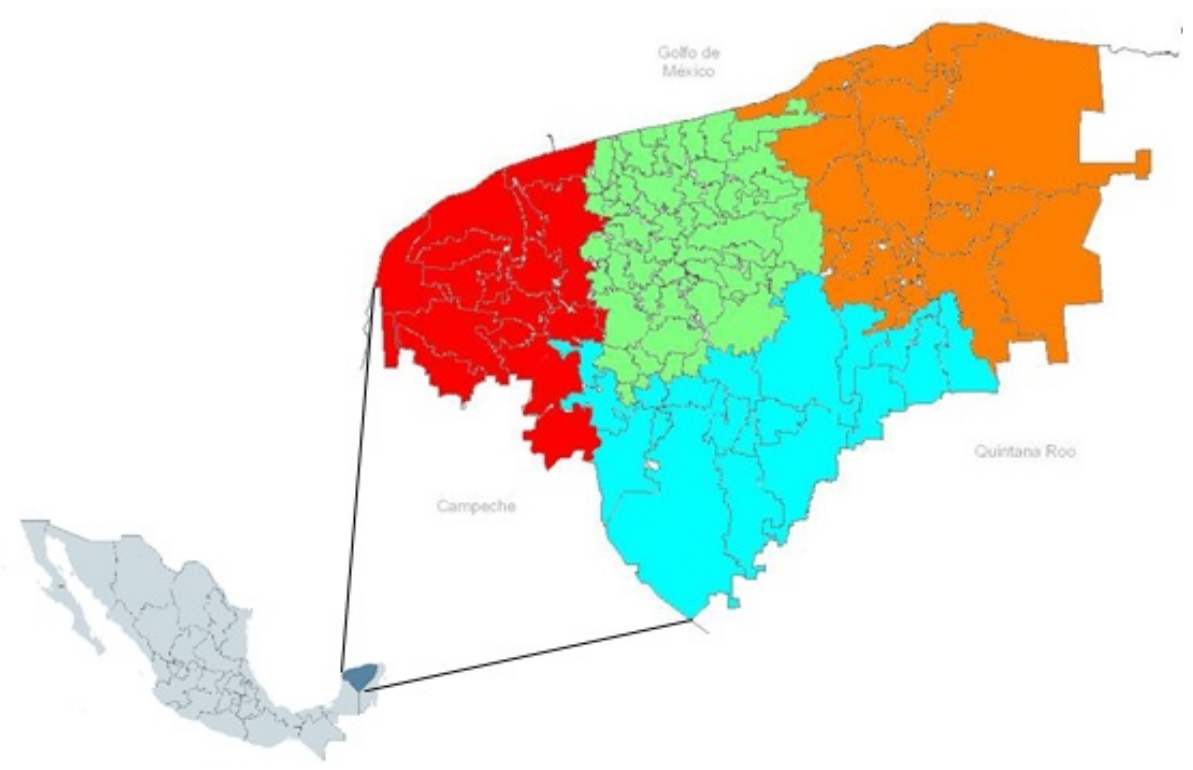

Figura 1. The four geographical areas of Yucatán state (from left to right): east, center, west and south, and its geographical location in Mexico.

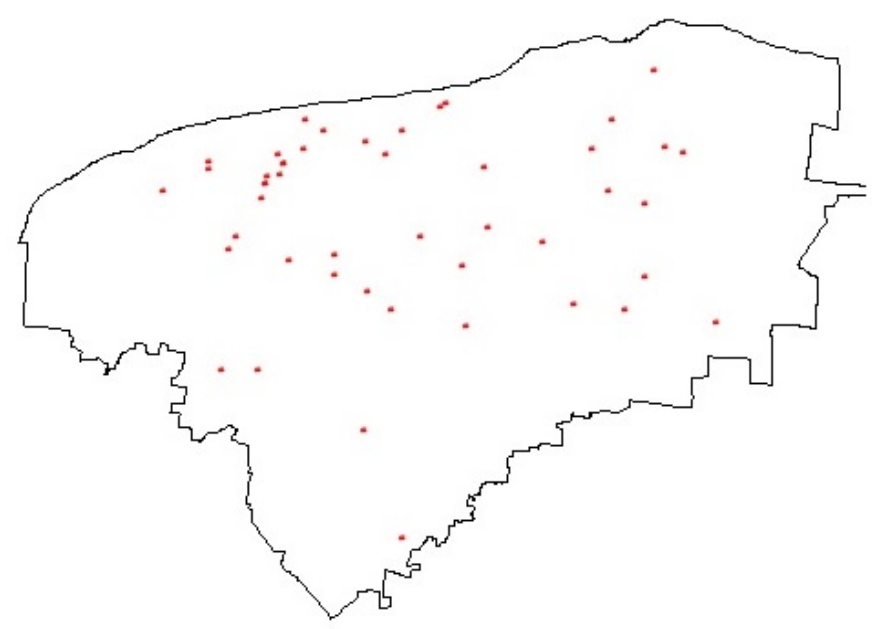

Figura 2. Location of the ovine farms sampled in Yucatán state.

13 samples from $E$ area, four samples from $S$ area and two samples from $W$ area. The predominant soil type in each sampled farm was identified and duly recorded (Bautista et al. 2007).

\section{Statistical analysis}

Means, standard deviation, and minimum and maximum values of data were estimated. Data were analyzed according to a completely randomized design with a factorial arrangement including the effects of the following factors: physiological situation of the ovine (recently weaned lambs, females prior to first gestation (yearlings) and adult ewes); the geographical location of the farm (C, $\mathrm{E}, \mathrm{S}, \mathrm{W}$ ); soil type in the farm (rendzina, litosol, luvisol, vertisol, cambisol); the interactions and the 
Tabla 1. Copper content in bone tissue of ovines $\left(\mathrm{mg} \mathrm{kg}^{-1}\right)$, in well water depending on its geographical location $(\mathrm{mg} / \mathrm{L})$ and based on the type of soil in the well location $\left(\mathrm{mg} \mathrm{L}^{-1}\right)$.

\begin{tabular}{lccccc}
\hline & $\mathrm{n}$ & Mean* & Standard deviation & Minimum & Maximum \\
\hline Physiological situation of ovine & \multicolumn{1}{c}{} & & & & \\
Recently weaned lambs & 34 & $0.66^{a}$ & 0.40 & 0.07 & 1.56 \\
Females prior to first gestation & 37 & $0.57^{b}$ & 0.40 & 0.07 & 1.57 \\
Adult ewes & 36 & $0.64^{a b}$ & 0.47 & 0.07 & 2.23 \\
Geographical location of the well in Yucatan state & & & & \\
Center & 21 & $0.15^{a b}$ & 0.04 & 0.08 & 0.22 \\
East & 13 & $0.12^{b}$ & 0.04 & 0.07 & 0.22 \\
South & 4 & $0.19^{a}$ & 0.03 & 0.16 & 0.23 \\
West & 2 & $0.16^{a b}$ & 0.07 & 0.12 & 0.21 \\
Predominant soil type in the ovine farms sampled & & & \\
Cambisol & 7 & $0.18^{a}$ & 0.05 & 0.08 & 0.23 \\
Litosol & 8 & $0.16^{a}$ & 0.03 & 0.12 & 0.20 \\
Luvisol & 4 & $0.14^{a}$ & 0.05 & 0.07 & 0.17 \\
Rendzina & 18 & $0.13^{a}$ & 0.05 & 0.07 & 0.22 \\
Vertisol & 3 & $0.12^{a}$ & 0.02 & 0.10 & 0.14 \\
\hline *Different letters in the same & & & & \\
\end{tabular}

experimental error (Montgomery 2004). Analyses were performed using Means and GLM routines of the SAS statistical software. When significant effects were detected in a variable, averages were compared through Tukey's test. All results were adjusted to a normal distribution.

\section{RESULTS AND DISCUSSION}

No interaction between the main effects tested was found; therefore, results are shown for each of the individual effects.

\section{Copper in bone biopsy}

The results of mineral content in sheep bone tissue, depending on the physiological state of the animals, are found in Table 1 . The lowest mean value was found in the females prior to gestation but it was similar to the one found in adult ewes ( $p$ $>0.05$ ). Weaned lambs had the highest amount of bone $\mathrm{Cu}(\mathrm{p}<0.05)$. Data dispersion was greater in bone tissue of adult ewes, since the standard deviation was the biggest (0.47).

The average content of bone $\mathrm{Cu}$ in sheep disregarding the physiological situation of the animals was $0.62 \mathrm{mg} / \mathrm{kg}^{-1}$, an inferior value compared to the norm, which is $2.00 \mathrm{mg} \mathrm{kg}^{-1}$ (Fick et al. 1979). Only one animal had a normal concentration $\left(2.23 \mathrm{mg} \mathrm{kg}^{-1}\right)$. This result underlines a $\mathrm{Cu}$ deficiency in all the studied animals.

The mineral analysis of fodder is an incomplete tool for the diagnosis of the mineral status of grazing ruminants, since it considers neither the degree of intestinal absorption of minerals nor their metabolic utilization. One way to investigate mineral bioavailability is analyzing the mineral content of the animal's ribs. The ribs and axial skeleton are rehabilitated more rapidly than the long bones; therefore, it is there where mineral changes due to diet can be detected (Underwood and Suttle 1999). Therefore, the results of this experiment provide additional evidence to confirm the Cu deficiency reported previously in forages cultivated in the same zone (Vivas et al. 2011). Supplemental Cu must be included in the ovine diet in order to improve animal performance.

\section{Copper content in well water related to its geographical location}

Table 1 shows results of $\mathrm{Cu}$ concentration in the well water according to the geographical location of the sampled farms. Copper content in the east was lower $(p<0.05)$ than that found in other zones of the state, with the $S$ zone having the highest level. Dispersion parameters were similar in all zones, except in the $\mathrm{W}$ zone where data dispersion was approximately double that found in the other zones. 
The average $\mathrm{Cu}$ concentration from well water obtained in this experiment $\left(0.14 \mathrm{mg} \mathrm{L}^{-1}\right)$ can be considered low since it is far below the maximum $0.50 \mathrm{mg} \mathrm{L}^{-1} \mathrm{Cu}$ concentration suggested by SEDUE (1989) and FAO (1994) for animal drinking water. Higher levels of $\mathrm{Cu}$ are accepted in water for human consumption, which can have as much as $2.00 \mathrm{mg} \mathrm{L}^{-1}$ (SSA, 1994). The low content of $\mathrm{Cu}$ in well water found in this experiment may be attributed to its low amount in the soil, which is confirmed by the low $\mathrm{Cu}$ content found in forages sampled in the same area (Vivas et al. 2011).

\section{Copper in well water depending on the type of} soil

Results of effects of soil type on Cu content in water are shown in Table 1 . No statistical difference in the $\mathrm{Cu}$ content of water depending on the type of soil was found ( $p>0.05$ ). The largest variability of results was found in Cambisol, Luvisol and Rendzina type soils. The different types of soils did not prove to be an important factor in the concentration of $\mathrm{Cu}$. This is probably due to the fact that all the soil in Yucatán state has a karstic origin (Bautista et al. 2015). Based on the above, it is concluded that there is a $\mathrm{Cu}$ deficiency in ovine grazing in $\mathrm{Yu}$ catán state since bone $\mathrm{Cu}$ was found below normal values. The analysis of well water showed a very low $\mathrm{Cu}$ content which is a consequence of the low $\mathrm{Cu}$ amount in the soil.

\section{ACKNOWLEDGEMENTS}

This research was partially funded by the Mexican National Council for Science and Technology (CONACyT-SAGARPA-COFUPRO \# 12284); project "Mineral characterization in the soilplant-animal system in the Yucatan Peninsula and its application in animal nutrition".

\section{LITERATURE CITED}

Bautista F, Aguilar Y, Rivas H, Páez R (2007) Los suelos del estado de Yucatán. In: Martínez M, Cabañas M (ed). Importancia del Binomio Suelo-Materia Orgánica en el Desarrollo Sostenible. Agencia Española de Cooperación Internacional y el Centro de Edafología y Biología Aplicada de Segura de Murcia, España. pp: 11-42.

Bautista F, Frausto O, Ihl T, Aguilar Y (2015) Actualización del mapa de suelos del estado de Yucatán México: enfoque geomorfopedológico y WRB. Ecosistemas y Recursos Agropecuarios 2: 303-315.

Cabrera TE, Sosa RE, Castellanos RAF, Gutiérrez BA, Ramírez SJH (2009) Comparación de la concentración mineral en forrajes y suelos de zonas ganaderas del Estado de Quintana Roo, México. Veterinaria México 40: $167-179$.

Cetz UFH, Cervantes TJI, Sauri DE, Bores QRA, Castellanos RA (2005) Impacto del empleo de microminerales quelatados en la alimentación de rumiantes Livestock Research for Rural Development. http://www.Irrd.org/Irrd17/9/cetz17097.htm. Date consulted: December 8, 2015.

COTECOCA (1978) Comisión Técnica Consultiva para la Determinación de los Coeficientes de Agostadero. Coeficientes de agostadero del estado de Chihuahua. Chihuahua, Chih., México. SARH. 149p.

FAO (1994) Water quality for agriculture. Food and Agriculture Organization of the United Nations. Rome Italy. http://www.fao.org/DOCReP/003/T0234e/T0234E00.htm. Date consulted: November 22, 2016.

Fick KR, McDowell LR, Miles PH, Wilkinson MS, Kunk JD, Conrad JH (1979) Methods of mineral analysis for plant and animal tissues. (2nd edition) Animal Science Department, University of Florida. Gainesville, Fla. USA. 301p. 
Little DA (1972) Bone biopsy in cattle and sheep for studies of phosphorus status. Australian Veterinary Journal 48: 668-670.

McDowell RL Arthington J (2005) Minerales para el ganado en pastoreo en regiones tropicales. Cuarta edición. University of Florida. Gainesville, Fla USA. 30p.

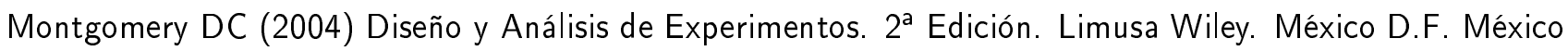
363p.

Millán CH, Aguirre GMA, Escamilla GI, Castellanos RAF (1990) Perfil mineral del pasto Guinea en el oriente de Yucatán. Veterinaria México 21: 399-402.

Muñoz GJC, Huerta BM, Ramírez VR, González AM (2015) Estado mineral y suplementación de óxido de cobre en cabras de San José Teacalco, Tlaxcala. Ecosistemas y Recursos Agropecuarios. 2: 203-210.

Muñoz-González JC, Huerta-Bravo M, Rangel-Santos R, Lara-Bueno A, De la Rosa-Arana JL (2014). Evaluación mineral de forrajes del trópico húmedo mexicano. Tropical and Subtropical Agroecosystems 17: $285-287$

NRC (2005) Mineral Tolerance of Animals. Second Revised Edition. The National Academies Press. National Academy of Sciences. Washington. 510p.

Saucedo-Terán RA, Holguín-Licón C, Jurado-Guerra P, Ochoa-Rivero JM, Rubio-Arias HO (2017) Cattle drinking water quality in the cow-calf beef operation in southern Chihuahua, Mexico. Ecosistemas y Recursos Agropecuarios 4: 331-340.

SEDUE (1989) Secretaría de Desarrollo Urbano y Ecología. Criterios Ecológicos de Calidad del Agua CE-CCA-001/89. Diario Oficial de la Federación, 13 de diciembre de 1989.

Segura CVM, Castellanos RAF (1999) Efecto de la suplementación fosforada sobre la ganancia de peso de bovinos en pastoreo en Yucatán, México. Veterinaria México 30: 257-262.

SSA (1994) Secretaría de Salud de México. Norma Oficial Mexicana NOM-127-SSA1- Agua para uso y consumo humano. Límites permisibles de calidad y tratamientos a los que debe someterse el agua para su potabilización, in Diario Oficial de la Federación, 30 de noviembre.

Suttle N (2010) Mineral nutrition of livestock, 4th Edition. CABI International. Oxfordshire UK. 255p.

Underwood EJ, Suttle NF (1999) Mineral nutrition of livestock. Third Edition. CABI Publishing International University Press. Cambridge UK. 587p.

Vázquez AJF, Rojo R, García RM, López D, Salem AFZ, Domínguez IA, et al. (2011) Effect of season on serum copper and zinc concentrations in crossbred goats having different reproductive status under semiarid rangeland conditions in southern México state. Tropical and Subtropical Agroecosystems 14: 331-335.

Vivas MEF, Rosado RJG, Castellanos RAF, Heredia AM, Cabrera TE (2011) Contenido mineral de forrajes en predios de ovinocultores del estado de Yucatán. Revista Mexicana de Ciencias Pecuarias 2: 465-475.

Whitehead CD (2000) Nutrient elements in grassland. Soil-Plant-Animal relationships. CABI Publishing International University Press. Wallingford. UK. 155p. 